\title{
Immediate and long-term clinical outcome of coronary angioplasty in patients aged 35 years or less
}

Marcel J Kofflard, Peter P de Jaegere, Ron van Domburg, Peter Ruygrok, Marcel van den Brand, Patrick W Serruys, Pim J de Feyter

\begin{abstract}
Objective-To study the immediate and long-term clinical success of percutaneous transluminal coronary angioplasty in patients aged 35 years or less.

Design-Patients undergoing percutaneous transluminal angioplasty were prospectively entered into a dedicated database. Clinical and angiographic data on all patients aged 35 years or less were reviewed. Follow up data were collected by interview during outpatient visits, by questionnaire, or from referring physicians.
\end{abstract}

Setting-A tertiary referral cardiac centre.

Patients-57 patients aged 35 years or less (median 33, range 22-35) underwent coronary angioplasty because of unstable angina (32 patients), stable angina (23 patients), acute myocardial infarction (1 patient), and documented ischaemia in a cardiac transplant patient.

Results-The primary clinical success rate (reduction in diameter stenosis to $<50 \%$ without in-hospital events) was $88 \%$. A major procedure related complication occurred in 5 patients ( $9 \%$ ): one patient died, two patients sustained an acute myocardial infarction, two patients underwent emergency bypass surgery, and in three patients repeat angioplasty was performed before hospital discharge. In 2 patients (4\%) coronary angioplasty did not significantly reduce the diameter stenosis but there were no associated complications. A total of 60 lesions were attempted (balloon angioplasty in 57, directional atherectomy in 2). The initial angiographic success rate was $92 \%$. The median (SD) follow up was 4.7 (3.0) years. During follow up 7 patients (12\%) died, 10 sustained a myocardial infarction (18\%), and 28 patients (49\%) underwent repeat revascularisation (coronary artery bypass grafting in $7(12 \%)$ and repeat angioplasty in $21(37 \%)$ ). The estimated 5 year survival and event-free survival (Kaplan-Meier method) was 87 (9)\% and 50 (13)\%, respectively. Multivariate logistic regression analysis showed that hypertension and the extent of vessel disease were the only independent predictive factors for event free survival. Conclusions-In young patients coronary angioplasty had a high immediate success rate but many needed repeat revascularisation procedures during the follow up period and survival was not improved. Coronary angioplasty in young patients should be regarded as a palliative procedure.

(Br Heart f 1995;73:82-86)

Keywords: coronary angioplasty, young patients.

Obstructive coronary artery disease has been found in young healthy individuals. ${ }^{12}$ Clinical expression of early-onset disease is rare, however, and is generally regarded as indicating a rapidly progressive disorder with poor outcome. The annual mortality ranges from $4 \%$ to $7 \% .^{34}$ Coronary artery bypass grafting (CABG) relieves angina and may improve outcome in selected patients. ${ }^{5}$ But the longterm clinical outcome of CABG is less satisfactory in young patients. ${ }^{6-8}$ Some studies have indicated that coronary angioplasty may offer a better alternative. ${ }^{9-11}$ To further elucidate the role of coronary angioplasty in young patients, we studied the immediate and longterm clinical outcome of this procedure in $\mathbf{5 7}$ patients aged 35 or less.

Table 1 Clinical and angiographic characteristics in 57 patients aged 35 or less

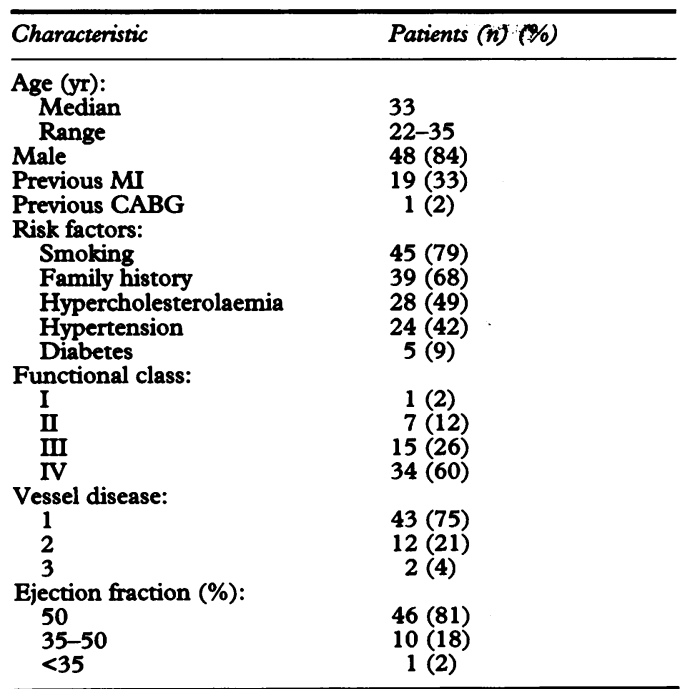

CABG, coronary artery bypass grafting; MI, myocardial infarctions. 


\section{Patients and methods}

PATIENTS

Between January 1981 and July 1992 coronary angioplasty was performed in 57 patients aged 35 or less. In this period a total of 5790 patients had coronary angioplasty. Table 1 shows the clinical and angiographic characteristics of these young patients. The indication for coronary angioplasty was stable angina in 23 patients $(40 \%)$, unstable angina in 32 patients (56\%) (Braunwald II or IIIB in 15 patients (26\%) and Braunwald II or IIIC in 17 patients $(30 \%)$ ), acute myocardial infarction in another patient, and documented ischaemia in a cardiac transplant patient. ${ }^{12}$ Medical charts were reviewed for data on risk factors including hypercholesterolaemia (positive history associated with therapy or serum cholesterol $\geqslant 6.5 \mathrm{mmol} / \mathrm{l}$ ), hypertension (systolic and/or diastolic blood pressure $\geqslant 145$ and/or $95 \mathrm{~mm} \mathrm{Hg}$, respectively), cigarette smoking (smoking within the last year before the intervention), and family history of coronary artery disease anddiabetes.

CORONARY ARTERIOGRAPHY AND ANGIOPLASTY Coronary arteriography and angioplasty were performed by standard techniques as described elsewhere. ${ }^{13}$ Angioplasty was regarded as angiographically successful when the stenosis was reduced to less than $50 \%$ of the luminal diameter narrowing. A dissection was defined as the presence of intimal damage producing an intraluminal defect on the coronary angiogram and/or extraluminal extravasation of contrast material and/or the presence of linear luminal density or luminal staining. A clinically successful angioplasty was defined as an angiographically successful dilatation free of procedure related complications leading to death, acute myocardial infarction, emergency bypass surgery, or repeat angioplasty. A periprocedural infarction was determined by the development of new $Q$ waves or an increase in the serum cardiac enzymes of more than twice the upper limit of normal.

\section{FOLLOW UP}

Procedural details, including immediate complications, were prospectively entered at the time of the intervention into a dedicated computer database. The median (SD) follow up time was $4.7(3.0)$ years (range 1-11). Patients were screened for the occurrence of death, acute myocardial infarction, and recurrent angina pectoris necessitating repeat angioplasty or bypass surgery. Clinical follow up information was obtained retrospectively by interview during outpatient visits, questionnaire, or from the referring physiciar. Information was complete for all patients. Patient survival curves and event free plots were constructed by the Kaplan-Meier method. We used multivariate logistic stepwise regression analysis to determine independent predictors of event free survival. The following variables were selected: age, gender, current smoking; hypercholesterolaemia, hypertension, diabetes, family history, stable
Table 2 Lesion site and type of 57 patients aged 35 or less (60 lesions attempted)

\begin{tabular}{lc}
\hline Lesion & No (\%) \\
\hline Lesion site: & \\
LAD & $38(63)$ \\
RCA & $18(30)$ \\
LCX & $4(7)$ \\
Lesion type ${ }^{\star}:$ & $5(8)$ \\
A & $44(73)$ \\
B & $11(18)$ \\
\hline
\end{tabular}

${ }^{\star}$ Classification according to the guidelines of the American College of Cardiology/American Heart Association Task Force on assessment of diagnostic and therapeutic cardiovascular procedures. ${ }^{29}$

LAD, left anterior descending; RCA, right coronary artery; LCX, left circumflex.

or unstable angina, history of myocardial infarction, ejection fraction less than $50 \%$, single or multiple vessel disease, type $\mathrm{C}$ or type A/B lesion, angioplasty before or after 1985, and presence of dissection after angioplasty.

\section{Results}

\section{ANGIOGRAPHIC RESULTS}

Coronary angioplasty was performed in 57 patients aged 35 or less (balloon angioplasty in 55 and directional atherectoriny in two). A total of 60 lesions were attempted (one lesion in 54 and two lesions in three patients). Table 2 shows the lesion site and type. Fifty five lesions were successfully dilated, resulting in an overall primary angiographic success rate of $92 \%$. The lesion could not be crossed in two patients (4\%). Abrupt vessel closure immediately after attempted angioplasty occurred in three other patients $(5 \%)$ : one was referred for urgent bypass surgery, one underwent bail-out stent implantation, and the remaining patient was treated with prolonged balloon dilatation. The postoperative course was uneventful in all, except in the last patient who sustained a non- $Q$ wave myocardial infarction (creative kinase $322 \mathrm{U} / \mathrm{l}$ ).

\section{CLINICAL RESULTS}

The primary clinical success rate for the total study population was $88 \%$ (table 3 ). In two patients $(4 \%)$ the angioplasty did not reduce the diameter stenosis, there were no complications. Five patients ( $9 \%$ ) sustained a major procedure related complication. One female patient, admitted because of an acute myocardial infarction complicated by cardiogenic shock, died 24 hours after successful

Table 3 Clinical success of coronary angioplasty and procedure related complications in 57 patients aged 35 or less

\begin{tabular}{lc}
\hline & No (\%) \\
\hline Clinical success & $50(88)$ \\
Unsuccessful angioplasty without complications & $2(4)$ \\
Unsuccessful angioplasty with complications: & $5(9)$ \\
Death & $1(2)$ \\
AMI & $2(4)$ \\
CABG & $2(4)$ \\
Bail-out stent/repeat PTCA (acute closure) & $3(5)$ \\
\hline
\end{tabular}

AMI, acute myocardial infarction, CABG, coronary artery bypass grafting; PTCA, percutaneous trainsluminal coronary angioplasty. 
Table 4 Major cardiac events during hospital stay and after discharge in 57 patients aged 35 or less

\begin{tabular}{llcr}
\hline Event & $\begin{array}{l}\text { In hospital } \\
(n=57) \\
\text { No }(\%)\end{array}$ & $\begin{array}{l}\text { After discharge } \\
\left(n=56^{\star}\right) \\
\text { No }(\%)\end{array}$ & $\begin{array}{l}\text { Total } \\
(n=57) \\
\text { No }(\%)\end{array}$ \\
\hline Death & $1(2)$ & $6(11)$ & $7(12)$ \\
AMI & $2(4)$ & $8(14)$ & $10(18)$ \\
CABG & $2(4)$ & $5(9)$ & $7(12)$ \\
Re-PTCA & $3(5)$ & $18(32)$ & $21(37)$ \\
Total of events & $8(14)$ & $37(66)$ & $45(79)$ \\
\hline
\end{tabular}

*One hospital death. See footnote to table 3 for abbreviations.

reperfusion and dilatation of an occluded left anterior descending artery. In two other patients, balloon angioplasty was complicated by an non-fatal acute myocardial infarction (serum creatine kinase 1200 and $322 \mathrm{U} / \mathrm{l}$ ). Acute vessel closure occurred in three other patients: 1 was referred for emergency bypass surgery, one was managed with a bail-out stent, and the remaining patient was treated conservatively. The postoperative course was uneventful in all. Thus a total of eight events occurred in five patients. If the patient in whom angioplasty was performed because of acute myocardial infarction and cardiogenic shock is excluded there were seven events in four patients.

\section{FOLLOW UP RESULTS}

Table 4 lists the occurrence of major events after hospital discharge. There were six deaths (11\%) of which five were cardiac and one non-cardiac (cerebrovascular accident). Eight patients $(14 \%)$ sustained a non-fatal myocardial infarction. Eighteen patients (32\%) underwent repeat angioplasty during the follow up period (the same lesion in 14 patients, a newly acquired lesion in four and one of these was referred for emergency bypass surgery. A further five patients $(9 \%)$ underwent elective bypass surgery with an uncomplicated postoperative course. The mean (SD) estimated survival 5 years after the index angioplasty for the entire study population was 87 (9\%) (95\% confidence interval $78 \%$ to $96 \%$, figure). Event free survival at 5 years (free of myocardial infarction, bypass surgery, and repeat angioplasty) was $50(13 \%)(95 \%$ confidence interval $37 \%$ to $63 \%$, figure). The only independent predictors of event free survival were hypertension and the extent of vessel disease. The probability of sustaining a cardiac event was increased 11 -fold (95\% confidence interval 1.4 to 83.0 ) in patients with hypertension and $3 \cdot 5$-fold (95\% confidence interval 1.0 to 13.0 ) in patients with multivessel disease. At the end of follow up, $40(80 \%)$ of the 50 patients were still alive and symptom free, six patients were in New York Heart Association class II, and four patients were in class III.

\section{Discussion}

Atherosclerosis of the coronary arteries starts very early in life and progresses over decades. It generally becomes manifest clinically in the middle and the older age groups. ${ }^{14}$ None the less, $0 \cdot 3-4.0 \%$ of the patients with angiographically documented obstructive coronary artery disease and $0 \cdot 7-8.9 \%$ of the patients undergoing coronary artery bypass grafting or coronary angioplasty are aged 40 years or less. ${ }^{41015}$ The reported annual mortality in medically treated young patients ranges from $4.0 \%$ to $6.8 \%$ and contrasts with the reported annual mortality of $0.3 \%$ to $0.5 \%$ in age matched controls. ${ }^{3410}$ There is still uncertainty about whether age itself is an independent predictor of long-term survival. Both clinical and angiographic variables have been identified as independent predictors of mortality and event free survival. ${ }^{116}$ Whereas some found that multivessel disease and impaired left ventricular function predicted late mortality, Webb et al identified diabetes and hypertension as independent predictors of subsequent death. ${ }^{3116}$ The presence of coronary risk factors such as diabetes and raised concentrations of serum cholesterol, however, seem to have more influence on event free survival. ${ }^{316}$ In the present study, hypertension and multivessel disease were the
Survival and event free survival (Kaplan-Meier) of patients aged 35 or less who underwent coronary angioplasty.

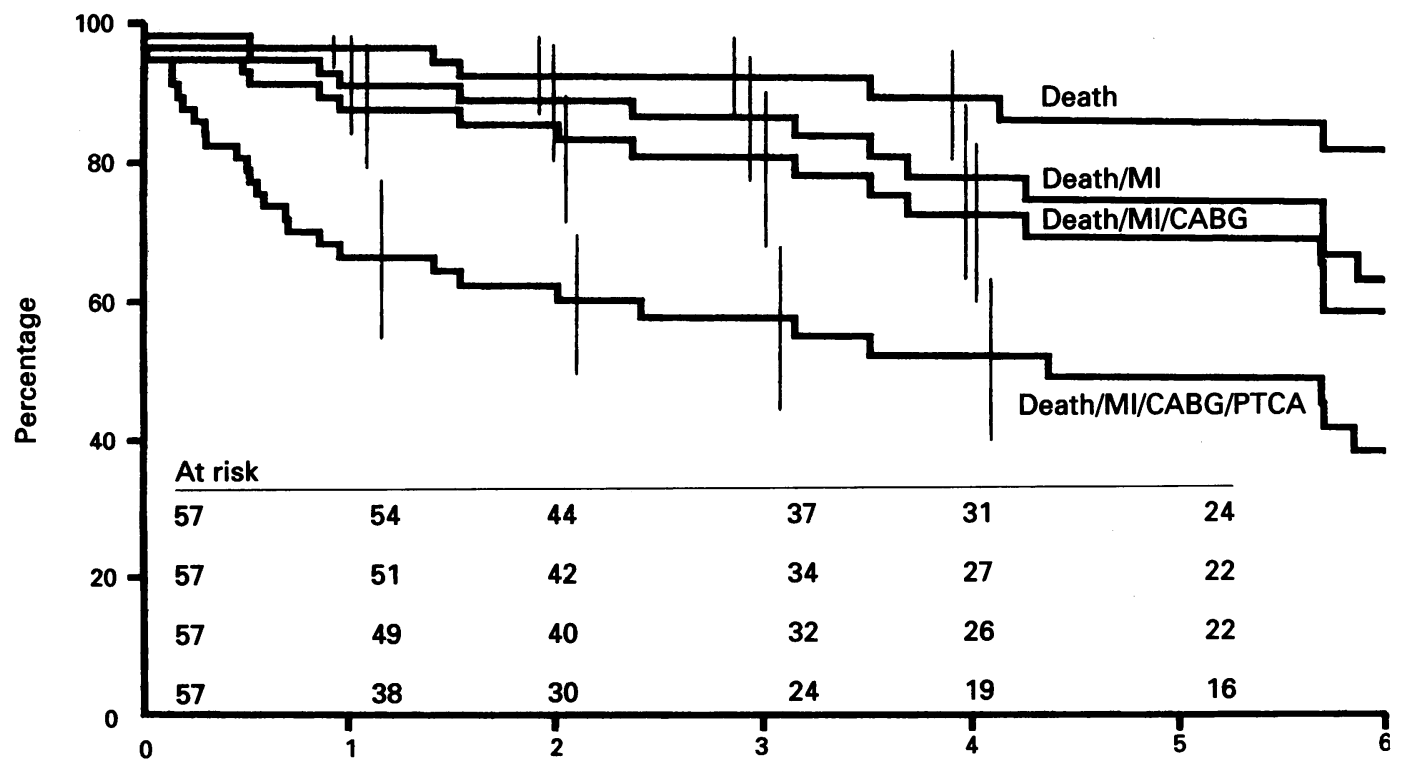


Table 5 Clinical events during hospital stay and after discharge in young patients who underwent coronary artery bypass grafting

\begin{tabular}{|c|c|c|c|c|c|c|c|c|c|c|c|c|c|}
\hline \multirow[b]{2}{*}{ Author } & \multirow[b]{2}{*}{$\begin{array}{l}\text { Study } \\
\text { period }\end{array}$} & \multirow[b]{2}{*}{ Cases } & \multicolumn{3}{|c|}{ Baseline characteristics (\%) } & \multicolumn{3}{|c|}{ Events in hospital (\%) } & \multicolumn{5}{|c|}{ Follow up data (Events (\%)) } \\
\hline & & & $\begin{array}{l}\text { Presence } \\
\text { of } M V D\end{array}$ & $L V E F$ & $\begin{array}{l}\text { History } \\
\text { of } A M I\end{array}$ & Death & $A M I$ & No (\%) & $\begin{array}{l}\text { Time } \\
\text { to FU (yr) } \\
\text { (Mean (SD) } \\
\text { or (range) }\end{array}$ & Death & $A M I$ & $C A B G$ & $\begin{array}{l}\text { Symptom } \\
\text { free at } \\
\text { end of } \\
F U(\%)\end{array}$ \\
\hline \multicolumn{14}{|c|}{ Patients 35 or less } \\
\hline $\begin{array}{l}\text { Lytle, et all } \\
\text { Cohen, et } a l^{6}\end{array}$ & $\begin{array}{l}71-75 \\
70-80\end{array}$ & $\begin{array}{r}107 \\
41\end{array}$ & $\begin{array}{l}63 \\
73\end{array}$ & $\begin{array}{l}\text { Normal in } 70 \% \\
62(2 \cdot 4)\end{array}$ & $\overline{66}$ & $\begin{array}{l}0.9 \\
4.9\end{array}$ & $\begin{array}{l}\mathbf{4 \cdot 6} \\
\text { NR }\end{array}$ & $\begin{array}{c}106(100) \\
39(95)\end{array}$ & $\begin{array}{l}9 \cdot 6(1 \cdot 4) \\
5 \cdot 0(1-13)\end{array}$ & $\begin{array}{l}14 \cdot 1 \\
19 \cdot 5\end{array}$ & $\begin{array}{l}21 \cdot 6 \\
\text { NR }\end{array}$ & $\begin{array}{l}12 \cdot 5 \\
12 \cdot 1\end{array}$ & $\underline{65}$ \\
\hline $\begin{array}{l}\text { Almeida de Olivera, et } a^{26} \\
\text { Laks, et } a l^{20} \\
\text { Kelly, et } a l^{17} \\
\text { Jones, et } a l^{19} \\
\text { Gelfand et a }{ }^{27} \\
\text { Fitzgibbon, et } a l^{8} \\
\text { Kelly, et } a l^{7}\end{array}$ & $\begin{array}{l}69-74 \\
76-77 \\
71-77 \\
71-78 \\
70-80 \\
72-85 \\
68-84\end{array}$ & $\begin{array}{r}100 \\
70 \\
68 \\
116 \\
92 \\
138 \\
242\end{array}$ & $\begin{array}{l}84 \\
61 \\
74 \\
\text { NR } \\
68 \\
85 \\
\text { NR }\end{array}$ & $\begin{array}{l}\text { Normal in } 30 \% \\
\text { Normal in } 35 \% \\
\text { NR } \\
\text { Normal in } 52 \% \\
46 \\
\text { Normal in } 58 \% \\
\text { NR }\end{array}$ & $\begin{array}{l}\text { Patients } 4 \\
64 \\
49 \\
53 \\
\frac{58}{54} \\
47\end{array}$ & $\begin{array}{l}\text { or less } \\
0 \\
0 \\
0 \\
0 \\
3 \cdot 3 \\
0 \\
2 \cdot 9\end{array}$ & $\begin{array}{l}2 \\
4 \\
1 \cdot 5 \\
1 \cdot 7 \\
3 \cdot 3 \\
4 \cdot 3 \\
\text { NR }\end{array}$ & $\begin{array}{c}84(84) \\
69(99) \\
68(100) \\
(98) \\
62(67) \\
85(0) \\
172(74)\end{array}$ & $\begin{array}{l}2 \cdot 7(1-5) \\
2 \cdot 7(0 \cdot 5-4) \\
1 \cdot 0-6 \cdot 2 \\
1 \cdot 0-9 \cdot 0 \\
3 \cdot 5(0 \cdot 5-9) \\
\geqslant 10 \\
7 \cdot 9\end{array}$ & $\begin{array}{r}2 \cdot 0 \\
3 \cdot 8 \\
5 \cdot 9 \\
6 \cdot 9 \\
3 \cdot 2 \\
13 \cdot 8 \\
10 \cdot 5\end{array}$ & $\begin{array}{l}3 \\
8 \\
\geqslant 2 \cdot 9 \\
\overline{N R} \\
\geqslant 7 \cdot 9 \\
\text { NR }\end{array}$ & $\begin{array}{l}\text { NR } \\
2 \cdot 9 \\
= \\
-4 \cdot 8 \\
16 \cdot 6 \\
16 \cdot 2\end{array}$ & $\begin{array}{l}78 \\
67 \\
47 \\
79 \\
\text { NR } \\
62 \cdot 5\end{array}$ \\
\hline
\end{tabular}

See footnote to table 3 for abbreviations. FU, follow up; MVD, multiple vessel disease; NR, not reported.

only independent predictors of event free survival. These observations suggest that coronary atherosclerosis may be a more progressive disease in the subset of young patients with a high coronary risk factor profile. In general, young patients with coronary artery disease are known to have a higher incidence of coronary risk factors, especially hypercholesterolaemia, cigarette smoking, and family history of coronary artery disease. ${ }^{4717}$ Although, several studies indicate that reducing serum cholesterol may favorably influence progression of coronary atherosclerosis, it still remains uncertain whether risk factor modification improves longevity and event free survival. ${ }^{17-19}$

In addition to interventions aimed at prevention, palliation is of the utmost importance. Though coronary revascularisation techniques do not address the pathophysiology of the underlying disorder and thus cannot be expected to cure or halt the process of atherosclerosis, they can relieve symptoms. There is no doubt that coronary artery bypass grafting can be performed safely and effectively in young patients (table 5). However, it is a major intervention and vein graft failure has been reported to be higher in young patients than in the general population. ${ }^{161720}$ As a result younger patients are more likely to need reoperation than middle aged and older patients. ${ }^{67}$ No relation could be established between the presence of coronary risk factors and the inferior patency rate in young individuals. ${ }^{819}$ Young age at the initial operation is the single most important predictor of the need for subsequent reoperation. ${ }^{21}$ Reoperation is not only associated with an increased risk of perioperative myocardial infarction but also with less successful relief of symptoms. ${ }^{8}$ To overcome the problem of vein graft failure, Lytle et al advocated the use of internal mammary artery grafts. ${ }^{16}$ In their series of 107 patients aged 35 and less, they reported a patency rate of $93 \%$ at a mean postoperative interval of 47 months that was significantly higher than the patency rate of $56 \%$ for vein grafts. ${ }^{16}$ Because of the progressive nature of atherosclerosis in the young it remains to be seen whether this will be translated into enhanced palliation and superior long-term clinical outcome. Cosgrove et al found that the absence of an internal mammary artery graft was an adverse predictor of reoperation-free survival only in patients older than 40 but not in those younger than 40 years. ${ }^{21}$ In these patients, hypertension and smoking were the only risk factors predictive of reoperation-free survival.

It is not appropriate to use earlier surgical series as historical controls for comparing the results of surgery with those of coronary angioplasty, because both surgical and anaesthesiological techniques have improved considerably and surgical patients are more likely to have multiple vessel involvement. However, it seems that angioplasty can be performed with a similar or an even higher immediate success rate and safety than coronary artery bypass grafting (tables 5 and 6). Rates for perioperative death and acute myocardial infarction range from $0 \%$ to $2 \%$ and from $0 \%$ to $5 \%$ respectively after balloon angioplasty compared with $0 \%$ to $5 \%$ and $2 \%$ to $5 \%$ respectively after surgery. Furthermore, there is no difference in the procedural success rate of balloon angioplasty between young patients and all patients. Reported

Table 6 Clinical events during hospital stay and after discharge in young patients who underwent PTCA

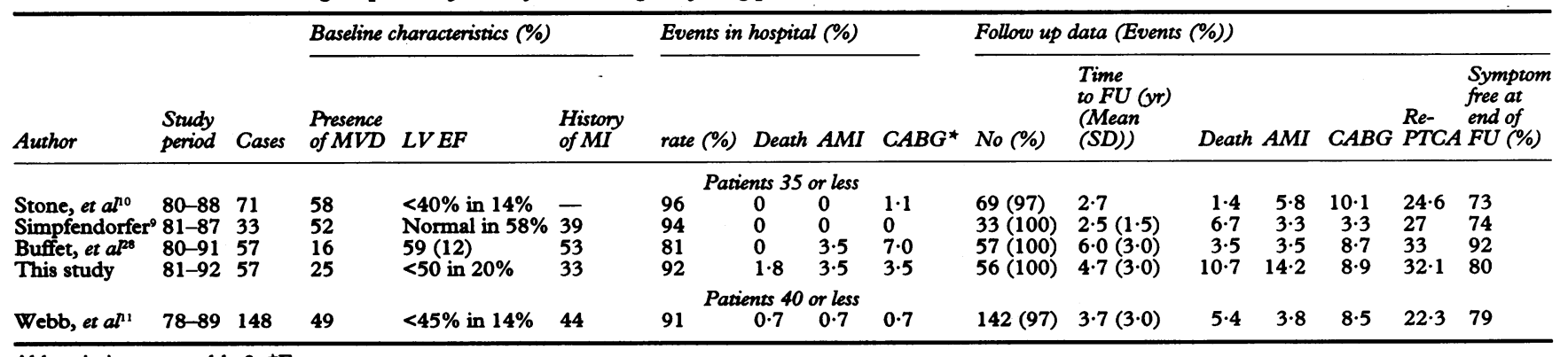

Abbreviations: see table 3. ${ }^{\star}$ Emergency. 
overall perioperative mortality and incidence of acute myocardial infarction range from $0 \%$ to $1.2 \%$ and from $0 \%$ to $4.9 \%$ respectively. ${ }^{22-24}$ Moreover, the use of the intracoronary stent may enhance the safety of the procedure by reversing acute or threatened vessel closure, thus reducing the risk of fatal or non-fatal periprocedural acute myocardial infarction and need for emergency bypass surgery. ${ }^{25}$

Long-term clinical outcome is not as good as the immediate results, however. In the present study, the estimated 5 year survival was $87 \%$. Thus the annual mortality is $3 \%$, which is higher than the annual mortality reported in other studies (table 6). In the other studies annual mortality after balloon angioplasty ranged from $0.4 \%$ to $1.0 \%$, which is lower than the reported annual mortality rate of $1 \cdot 0 \%$ to $2.0 \%$ after bypass surgery. The difference in annual mortality between our study and earlier ones is probably the result of differences in sample size and the duration of follow up. Long-term event free survival, which was $50 \%$ in our study, is predominantly determined by a high need for repeat revascularisation, either by bypass surgery or by repeat balloon angioplasty (table 6 ). In addition, many patients sustained an acute myocardial infarction. These combined data may indicate that coronary atherosclerosis in young patients is indeed rapidly progressive. This is highlighted by the observation that in other studies intervention was performed because of progression of disease and not because of restenosis in $14-53 \%$ of the patients requiring redilatation..$^{9-11}$ In our study, four (22\%) of the 18 patients underwent angioplasty of a newly acquired lesion. Because most of the follow up information was obtained by contacting the referring physician, some events may not have been identified and the reported event rate may underestimate the real incidence of events in the follow up period.

Our study has two main limitations. Its design does not allow a direct comparison of medical, surgical, and angioplasty treatments in young patients with coronary artery disease, and it may have been too small to identify all the independent predictors of long-term mortality and/or event-free survival. We now manage young patients with symptoms by intensive risk factor modification in combination with balloon angioplasty. Though this approach effectively relieves symptoms but the need for repeat revascularisation is high. Furthermore, it does not seem to improve the outcome in this group of patients.

1. Yater WM, Traum AH, Brown WG, Fitzgerald RH, Geisler MA, Wilcox BB. Coronary artery disease in men eighteen to thirty-nine years of age. Am Heart $f$ 1948; 36:683-722.

2 Enos WF, Holmes RH, Beyer JC. Coronary disease among United States soldiers killed in action in Korea. $\mathfrak{F} A M A$ 1953;152:1090-3.

3 Lim JS, Proudfit WL, Stones FM. Selective coronary arteriography in young men. A follow-up of 449 patients. Circulation 1974;49:1122-6.

4 Underwood DA, Proudfit WL, Lim J, MacMillan JP. Symptomatic coronary artery disease in patients aged 21 to 30 years. Am $\mathcal{G}$ Cardiol 1985;55:631-

5 Lawrie GM, Morris GC, Howell JF, Tredici T, Chapman $\mathrm{DW}$. Improved survival beyond 5 years in 1108 patients undergoing coronary bypass. Am $f$ Cardiol 1978;14: 355-62.

6 Cohen DJ, Basamania C, Graeber GM, Deshong J, Burge RJ. Coronary artery bypass grafting in young patients under 36 years of age. Chest 1986;89:811-6.

7 Kelly ME, DeLaria GA, Najafi $H$. Coronary artery bypas surgery in patients less than 40 years of age. Chest 1988;94:1138-41.

8 Fitzgibbon GM, Hamilton MG, Leach AJ, Kafka HR, Markle $\mathrm{H}$, Keon WJ. Coronary artery disease and coronary bypass grafting in young men: Experience with 138 1987;9:977-88.

9 Simpfendorfer C, Tuzcu EM, Badhwar K, Dorosti K, Franco I, Hollman J, et al. Percutaneous transluminal coronary angioplasty in the young adult. Cleve Clin $\mathcal{F}$ Med 1989;56:569-72.

10 Stone GW, Ligon RW, Rutherford BD, McConahay DR, Hartzler GO. Short-term outcome and long-term follow-up following coronary angioplasty in the young patient: An 8-year experience. Am Heart $f$ 1989;118: patient:

11 Webb JG, Myler RK, Shaw RE, Anwar A, Stertzer SH. Coronary angioplasty in young adults: Initial results and late outcome. F Am Coll Cardiol 1990;16:1569-74.

12 Braunwald E. Unstable angina. A classification. Circulation 1989;80:410-4

13 de Jaegere $P$, de Feyter $P$, van Domburg $R$, Suryapranata $H$, van den Brand $M$, Serruys $P W$. Immediate and long term results of percutaneous coronary angioplasty in patients aged 70 and over. $\mathrm{Br}$ Heart $f$ 1992;67:138-43.

14 Stary HC. Changes in the cells of the atherosclerotic lesions as advanced lesions evolve in coronary arteries of children and young adults. In: Glagov S, Newman WP III, Schaffer SH, eds Pathobiology of the human atherosclerotic plaque. Berlin: Springer Verlag, 1990;93-106.

15 Klein LW, Agarwal JB, Herlich MB, Leary TM, Helfant RH. Prognosis of symptomatic coronary artery disease in young adults aged 40 years or less. Am $f$ Cardiol 1987; 60:1269-72.

16 Lytle BW, Kramer JR, Golding LR, Cosgrove DM, Borsh JA, Goormastic M, et al. Young adults with coronary JA, Goormastic M, et al. Young adults with coronary artherosclerosis: 10 year results of surgical myocar

17 Kelly TF, Craver JM, Jones EL, Hatcher Jr. CR. Coronary revascularization in patients 40 years and younger: surgical experience and long-term follow-up. Am Surgeon 1978;67:675-8.

18 Vos J; de Feyter PJ, Simoons ML, Tijssen JGP, Deckers JW. Retardation and arrest of progression or regression of coronary artery disease: a review. Prog Cardiovasc Dis 1993;35:435-54.

19 Jones JW, Ochsner JL, Mills NL, Hughes L. Long-term results of myocardial revascularization in early-onset arteriosclerosis. Surgery 1980;88:760-5.

20 Laks H, Kaiser GC, Barner HB, Codd JE, Willman VI. Coronary revascularization under age 40 years. Risk
factors and results of surgery. $A m \stackrel{\Im}{ }$ Cardiol 1978;41: 584-9.

21 Cosgrove DM, Loop FD, Lytle BW, Gill CC, Golding LAR, Gibson C, et al. Predictors of reoperation after myocardial revascularization. $\mathcal{F}$ Thorac Cardiovasc Surg 1986;92:811-21.

22 Detre K, Holubkov R, Kelsey S, Cowley M, Kent K, Williams $\mathrm{D}$, et al and the co-investigators of the National Heart, Lung and Blood Institute's Percutaneous transHeart, Lung and Blood Institute's Percutaneous transluminal coronary angioplasty in 1985-1986 and 1977-1981. The National Heart, Lung, and

23 Serruys $P W$, Rutsch $\mathbb{W}$, Heyndrickx GR, Danchin N, Mast G, Wijns W, et al for the Coronary Artery Restenosis Prevention On Repeated Thromboxaneantagonism study group (CARPORT). Prevention of restenosis after percutaneous transluminal coronary angioplasty with thromboxane $\mathrm{A}_{2}$-receptor blockade. Circulation 1991;84:1568-80

24 Topol EJ, Leya F, Pinkerton CA, Whitlow PL, Hofling B, Simonton CA, et al for the Caveat Surgery group. A comparison of directional atherectomy with coronary angioplasty in patients with coronary artery disease. N Engl Y Med 1993;329:221-7.

25 de Jaegere PPT, de Feyter PJ, Serruys PW. Intracoronary stenting. In: Topol EJ, Serruys PW, eds. Current review of interventional cardiology. Philadelphia: Current Medicine, 1993;8・1-8:17.

26 Almeida de Oliveira S, Santana GP, Barchi CA, Marrara $\mathrm{JP}$, Carvalho VB, Arie S, et al. Direct myocardial $\mathrm{J}$, Carvalho $\mathrm{VB}$, Arie $\mathrm{S}$, et al. Direct myocardial secutive cases without operative mortality. $f$ Cardiovasc secutive cases with
Surg 1977;18:9-14.

27 Gelfand ET, Wartak J, Callaghan JC. Coronary artery bypass in patients under 40 years of age. Can $\Im$ Surg bypass in patients

28 Buffet $P$, Colasante B, Danchin N, Juilliere $Y$, Selton-Suty $\mathrm{C}$, Feldmann $\mathrm{L}$, et al. Long term results of coronary angioplasty in patients younger than 35 yea

29 Ryan TJ, Faxon DP, Gunnar RM, Kennedy JW, King III SB, Loop FD, et al. Guidelines for percutaneous transluminal coronary angioplasty: $A$ report of the American College of Cardiology/American Heart Association Task Force on assessment of diagnostic and therapeutic cardiovascular procedures (Subcommittee on percutaneous transluminal coronary angioplasty) $\mathcal{f} \mathrm{Am}$ Coll Cardiol 1988;12:529-45. 